\title{
FACTORS AFFECTING THE CHOICE OF HIGHER EDUCATION INSTITUTIONS BY PROSPECTIVE STUDENTS IN LATVIA
}

\author{
Nadezda Rika ${ }^{1}$, Jana Roze ${ }^{2}$, Irina Sennikova ${ }^{3}$
}

\begin{abstract}
Because of increasing competition among Latvian higher education institutions (HEIs), the administrators of these institutions are becoming increasingly interested in understanding how their potential students choose their institution. Comprehensive knowledge of consumer behavior allows institutions to become more effective at making good strategic marketing decisions and to better respond to customers' needs. The purpose of this study is to understand what factors affect the decision of secondary school leavers in choosing a particular higher education provider and the variables that might predict a student's choice. The research is based on data collected by the means of a survey distributed among final year students of Latvian secondary schools, with 644 responses analyzed using Spearman correlation and stepwise regression analysis. Analysis of four major groups of factors: cultural, social, psychological, and organizational, revealed that psychological and organizational factors are the best predictors of the choice of HEI. These explained $48 \%$ of the variance of the dependent variable $\left(\mathrm{R}^{2}=0.48 ; \mathrm{F}(1 ; 641)=293.46 ; \mathrm{p}<0.001\right)$. The results provide details of the factors with great importance to young people of Latvia in choosing their higher education provider. The HEI can use these factors for designing various student attraction strategies, and thus increase their market share and competitiveness.
\end{abstract}

JEL Classification Numbers: I23, DOI: http://dx.doi.org/10.12955/cbup.v4.790

Keywords: Higher education, HEIs, students' choice, Latvia.

\section{Introduction}

In recent years, the Latvian higher educational institutions (HEIs) have been facing increasingly complex challenges. Their operating environment is undergoing major transformation caused by changes in demand patterns, decline of government funding, and intensifying global and local competition. Nowadays, more than ever before, administrators of HEIs are confronting difficulties in efforts to identify, recruit, and enroll students. Change in demographic trends, increased competition for students, shifting student academic and career interests, and a shortage of financial resources are of serious concern to management of HEIs.

During recent years, competition among Latvian HEIs has intensified, mainly because of demographics relating to a dramatic birth rate decline during the 90 s with $51 \%$ decline observed between 1990 and 1998 (Central Statistical Bureau, 2013). As a consequence, the number of secondary school graduates has decreased, falling by 36\% from 2007 to 2014 (Central Statistical Bureau, 2015). In 2014, only 13.6 thousand pupils graduated from secondary school, $9.4 \%$ less than the previous year. Moreover, there are currently 32 HEIs in Latvia, offering 920 study programs (Academic Information entre, 2015), which, for a country the size of Latvia, is arguably too many. A recent increase in foreign student inflow to Latvian's educational system $(68 \%$ over the last five years), to a certain extent, offsets this situation, but does not diminish the importance of attracting local students. Another reason for decline in number of prospective students relates to the recent economic trends in Latvia. Overall, the paying ability of the population is low and in 2014, 60\% of Latvian education was tuition-fee based (Ministry of Education and Science, 2015). People found it difficult to cover the costs of higher education and subsequently choose to look for jobs and, when unable to find a suitable option in Latvia, chose to go abroad. Currently, $62.8 \%$ of school leavers pursue higher education, but this may decrease in the future.

As a response to a highly competitive environment, many HEIs develop and elaborate enrolment management strategies designed to influence the size and characteristics of the student body. As a result, marketing is becoming a central function within universities, helping the schools win the battle for prospective students. In this context, it is important to understand how young people choose a HEI for their studies and what factors affect their choice. This knowledge will allow institutions to better

\footnotetext{
${ }^{1}$ Nadezda Rika, RISEBA University, Riga, Latvia, nadezda.rika@ riseba.lv

2 Jana Roze, RISEBA University, Riga, Latvia, jana.roze@ riseba.lv

${ }^{3}$ Irina Sennikova, RISEBA University, Riga, Latvia, irina.sennikova@ riseba.lv
} 
leverage their resources, improve marketing efforts, and enhance the use of marketing budgets on strategies, programs, and services that influence students' enrolment behavior. With this knowledge, professionals can target and tailor their marketing messages to specific target markets and design and integrate proactive recruitment approaches. Knowledge of consumer behavior could be one of the most effective tools for HEIs to tackle the new highly-competitive environment.

\section{Literature Review}

Marketing in the higher education (HE) sector is not new. The potential benefits of marketizations have been recognized by scholars in the field of HE marketing worldwide (Kotler \& Fox, 1995; Hoyt \& Brown, 2003; Bragg, 2007; Yokoyama, 2008; Ivy, 2008; Datar, Garvin, \& Cullen, 2010). Research has shown that to survive, HEIs should use a marketing framework and satisfy the need of their customers by value-adding for a sustainable competitive advantage (Hoyt and Brown, 2003; Kotler and Fox, 1995). This can be achieved by applying an effective mix of marketing tools to influence the demand for services that HEIs offer (Ivy, 2008).

As a service, HE marketing is sufficiently different from the marketing of products (Nicholls, Harris, Morgan, Clarke, \& Sims, 1995). The management of a HEI needs to market their institution to establish its uniqueness, highlighting its strengths and giving students a reason to choose that institution. Therefore, many researchers have indicated that marketing plays an important role in student recruitment, and these researchers have attempted to model how student's choose HEIs (Ellis and Moon, 1998; Kittle and Ciba, 2001; Ivy, 2001; Goff, Patino, \& Jackson, 2004; Judson, James, \& Aurand, 2004; Tapp, Hicks, \& Stone, 2004; Cubillo, Sánchez, \& Cerviño, 2006).

Models of student behavior emerged in the 1980s (Paulsen, 1990). These were based on models of consumer behavior and decision making. Most studies that have attempted to explain student choice of HEI can be categorized, according to Hossler, Schmidt, and Vesper (1999), as using one of three models: economic, status-attainment (sociological), or a combined model.

The economic models are based on econometric assumptions that prospective students act rationally and make careful cost-benefit analyses when choosing a HEI. Choice is treated as a rational process and it is believed that students will always do what is best for them in these models. The Kotler and Fox's (1995) model is a good example of such.

The status-attainment (sociological) models assume a variety of social and individual factors lead to educational aspirations, e.g. parental encouragement, influence of other persons, and academic performance.

Combined models try to capture the essence of both the previously mentioned models. Combined models assume multiple stages in the student decision-making process. These types involve a considerable amount of analytical effort, as they combine sociological aspects with rational decisions. An example of this type of model is the one of Hossler and Gallager (1987).

Kusumawati, Yanamandram, and Perera (2010) summarized a comparison of these models (Table 1), and choosing a HEI, according to Briggs and Wilson (2007) is highly complex, being subject to multiple influences.

Researchers have argued that the choice process is a complex decision for a student, not only in monetary terms, but also because it involves long-term effects on a student's life (Litten, 1980; Yost \& Tucker, 1995). According to Gati and Asher (2001), selecting a HEI is a decision-making process that could be included in a field of so-called career decision-making. The choice of HEI and the topic of career are closely related and according to Germeijs, Luyckx, Notelaers, Goossens, and Verschueren (2012), this creates a "mini-cycle" that is part of the whole career development cycle, which, according to Kotler and Fox (1995), can influence the student's future career, friendships, future residence, and personal satisfaction.

The theory of career decision-making is based on general decision-making models. These are, according to Gati and Tal (2008), typical for when an individual has to: (a) implement a decision, (b) achieve a goal or goals, (c) choose from alternatives, (d) consider factors in comparing alternatives, or (e) collect and process information (often under conditions of uncertainty). 
Table 1: Models of the Stages in Consumer Decision Making and Student Choice

\begin{tabular}{|c|c|c|c|c|c|c|}
\hline Authors & \multicolumn{6}{|c|}{ Consumer Decision Making and Student Choice Model } \\
\hline $\begin{array}{l}\text { Engle, Blackwell } \\
\text { and Miniard } \\
(1995 ; 2001)\end{array}$ & $\begin{array}{l}\text { need } \\
\text { recognition }\end{array}$ & $\begin{array}{l}\text { information } \\
\text { search }\end{array}$ & $\begin{array}{l}\text { evaluation } \\
\text { process }\end{array}$ & \multicolumn{2}{|c|}{$\begin{array}{l}\text { outlet selection and } \\
\text { purchase }\end{array}$} & $\begin{array}{l}\text { post-purchase } \\
\text { process }\end{array}$ \\
\hline $\begin{array}{l}\text { Schiffman and } \\
\text { Kanuk (2007) }\end{array}$ & $\begin{array}{l}\text { need } \\
\text { recognition }\end{array}$ & $\begin{array}{l}\text { pre-purchase } \\
\text { search }\end{array}$ & $\begin{array}{l}\text { evaluation of } \\
\text { alternatives }\end{array}$ & \multicolumn{2}{|c|}{ purchase } & $\begin{array}{l}\text { post-purchase } \\
\text { evaluation }\end{array}$ \\
\hline $\begin{array}{l}\text { Kotler and } \\
\text { Keller (2009) }\end{array}$ & $\begin{array}{l}\text { problem } \\
\text { recognition }\end{array}$ & $\begin{array}{l}\text { information } \\
\text { search }\end{array}$ & $\begin{array}{l}\text { evaluation } \\
\text { alternatives }\end{array}$ & \multicolumn{2}{|c|}{ purchase decision } & $\begin{array}{l}\text { post-purchase } \\
\text { behavior }\end{array}$ \\
\hline $\begin{array}{l}\text { Perreault and } \\
\text { McCarthy } \\
(2005)\end{array}$ & $\begin{array}{l}\text { need-want } \\
\text { awareness }\end{array}$ & $\begin{array}{l}\text { search for } \\
\text { information }\end{array}$ & $\begin{array}{l}\text { set criteria and } \\
\text { evaluate } \\
\text { alternative } \\
\text { solutions }\end{array}$ & $\begin{array}{l}\text { decide } \\
\text { on } \\
\text { solution }\end{array}$ & $\begin{array}{l}\text { purchase } \\
\text { product }\end{array}$ & $\begin{array}{l}\text { post-purchase } \\
\text { evaluation }\end{array}$ \\
\hline Chapman (1981) & pre-search & search & application & choice & enrolment & \\
\hline $\begin{array}{l}\text { Hanson and } \\
\text { Litten (1982) }\end{array}$ & $\begin{array}{l}\text { deciding to } \\
\text { go to } \\
\text { college }\end{array}$ & $\begin{array}{l}\text { investigating } \\
\text { colleges }\end{array}$ & \multicolumn{3}{|c|}{ application, admission, and enrolment } & \\
\hline Jackson (1982) & preference & - & exclusion & \multicolumn{2}{|c|}{ evaluation } & \\
\hline $\begin{array}{l}\text { Hossler and } \\
\text { Gallagher (1987) }\end{array}$ & pre-dispositi & search & & \multicolumn{2}{|l|}{ choice } & - \\
\hline $\begin{array}{l}\text { Kotler and Fox } \\
\text { (1985) }\end{array}$ & $\begin{array}{l}\text { initial } \\
\text { decision } \\
\text { to } \\
\text { investigate } \\
\text { college }\end{array}$ & $\begin{array}{l}\text { information } \\
\text { gathering }\end{array}$ & $\begin{array}{l}\text { evaluation and } \\
\text { elimination } \\
\text { of choices to } \\
\text { generate set of } \\
\text { options }\end{array}$ & \multicolumn{2}{|l|}{ choice } & \\
\hline
\end{tabular}

Along with other decisions that may have long-term consequences on the life of an individual, this kind of decision is also influenced by many factors. Several studies have attempted to investigate which factors influence students in their choice of HEI. Raposo and Alves (2007) mentioned that these studies can be viewed according to the stimulus-response model of consumer behavior, where students are faced with external stimulus, such as the institutionally controlled marketing vehicles, institutional attributes, and non-controllable factors, like personal influence of parents and friends. The diversity of factors influencing a student's choice is great. Many researchers in the field of student decisionmaking have examined the influence of:

- others: parents (Moogan \& Baron, 2003; Yamamoto, 2006; Domino, Libraire, Lutwiller, Superczynski, \& Tian, 2006; Raposo \& Alves, 2007; Al-Yousef, 2009); friends, peers, relatives, teachers, and other influential people (Ceja, 2004, 2006; Yamamoto, 2006; Pimpa \& Suwannapirom, 2008; Wagner \& Fard, 2009);

- personal factors (Dawes \& Brown, 2002; Kim, 2004; Nora, 2004; Yamamoto, 2006; Raposo \& Alves, 2007);

- geographic location (Veloutsou, Lewis, \& Paton, 2004; Wagner \& Fard, 2009; Beneke \& Human, 2010);

- institutional characteristics (teaching quality, prestige, infrastructure, library, computer facilities, location, quality of the curricula, scientific research quality, administrative support, extra-curricular factors, such as sports, leisure, and canteens, and the availability of exchange programs with foreign universities (Tavares, Tavares, Justino, \& Amaral, 2008);

- $\quad$ proximity to home (Paulsen, 1990; Raposo \& Alves, 2007; Dawes \& Brown, 2005); 
- reputation (Hoyt \& Brown, 2003; Briggs, 2006; Ancheh, Krishnan, \& Nurtjahja, 2007; Ho \& Hung, 2008; Wiese et al., 2009; Afful-Broni \& Noi-Okwei, 2010; Beneke \& Human, 2010);

- employment prospects (Wiese, van Heerden, Jordaan, \& North, 2009);

- price (Quigley, Bingham, Notarantonio, \& Murray, 2000; Domino et al., 2006; Wagner \& Fard, 2009; Beneke \& Human, 2010); and

- financial aid or packages that include scholarships and grants (Kim, 2004; Govan, Patrick, \& Yen, 2006; Hoyt \& Brown, 2003).

Research shows that there are many important factors that influence a HEI choice. As Kusumawati et al. (2010) stated each factor has a different level of importance for every country and each student. Hence, with Latvia as the context, this research specifically considers factors that are likely to predict plans of prospective students for higher education, in four categories: cultural, social, psychological, and organizational. The main objective of this study is to investigate variables that might forecast a student's choice of HEI and reach an understanding of which factors: cultural, social, psychological or organizational, play the greatest role in prospective student decision-making processes.

\section{Methodology}

Study sample

For the purposes of this research, probability sampling was used, i.e. all units of a general population had a certain probability of being included in the sample. The general population involved 10730 final year pupils (year 12) from Latvian secondary schools for the 2014-2015 academic year (Central statistical bureau, 2015). According to the traditional statistical method the size of the sample is calculated as:

$$
\mathrm{n}=\frac{t^{2} * \delta^{2} * N}{t^{2} * \delta^{2}+\Delta^{2} * N}
$$

where:

$\mathrm{N}=$ the size of the general population

$\delta=$ the variance of the studies trait

$\Delta=$ margin of error

$\mathrm{t}=$ confidence level

Inserting numerical values to the formula provided the following result:

$$
\mathrm{n}=\frac{2^{2} * 1^{2} * 10730}{2^{2} * 1^{2}+0.1^{2} * 10730}=\frac{4 * 1 * 10730}{4 * 1+0.01 * 10730}=42920 \div 111.30=385 \text { (people) }
$$

Consequently, the sample can be representative with a minimum number of 385 respondents.

There were 644 respondents in the study, all in the age range of 16 to 20 years $(\overline{\mathrm{X}}=18.35 ; \mathrm{SD}=0.82)$. Of these, $48 \%$ were female and $52 \%$ male. At the time of the field study, all respondents were final year pupils of Latvian secondary schools.

\section{Research Tools}

To define factors affecting a decision to enter HEI, the questionnaire was designed using the Likert scale of 1 (fully agree) to 5 (fully disagree). The plans of the respondents to enter HEIs were defined with the statement: "On completion of the secondary school I intend to enter HEI". During data processing, to obtain independent variables, items relating to choice of HEI were included in a factor analysis. This resulted in this study including four major groups of factors:

(i) Cultural factors (included 13 items, $\alpha=0.78$ ), to describe to what extent family culture regarding higher education, in general, affects the decision of a school leaver to go to a university or not, i.e. whether higher education is perceived as having value among family members and within a person's inner circle. This also considers issues relating to a person's religious affiliation, nationality, ethnic origin, and other culturally embedded societal norms and traditions, and aims to determine whether culture affects the decision of a school leaver. 
(ii) Social factors (included 25 items, $\alpha=0.90$ ), to define to what extent the opinion of other people, including family members, friends, and society at large, affect the behavior of respondents; how important income level is in a decision about HEI; the respondent's readiness to invest in their own education and development, including obtaining a loan.

(iii) Psychological factors (included 22 items, $\alpha=0.89$ ) to describe the attitude of the respondents towards higher education; their belief in the necessity and value of higher education. These also aim to present the view on the respondent's motives in choosing whether to receive a higher education or not.

(iv) Organizational factors (included 12 items, $\alpha=0.86$ ) to describe what characteristics, institutional specifics, or actions of the educational institutions themselves, might affect the prospective student's choice.

Procedure and data analysis

The data were collected during spring 2015. The questionnaires were distributed among respondents both, in a paper form with meeting the pupils personally, and electronically using the Webropol survey platform, which offers user-friendly survey techniques and ensures anonymity and confidentiality of the respondents.

The data were analyzed using IBM SPSS 22.0, Armonk, NY. Spearman correlations and a regression analysis, applying the stepwise method, were used.

\section{Research results}

According to the collected data, $69.5 \%$ of the respondents were willing to pursue higher education and $44 \%$ were thinking of combining studies at the HEI with work, i.e. studying on a part-time basis. The majority wished to receive higher education for personal development $(56 \%)$ or prestige $(51 \%)$. This means that while higher education is in demand, HEIs need to consider opportunities for students to combine studies with work, e.g. by offering flexible time schedules.

Of the respondents, 58\% did not take into account the recommendations of their friends and $73 \%$ ignored the advice of their teachers. These results were supported by statements that "getting higher education is solely my decision" (64\%), and corresponded to "my personal interests and abilities" (71\%). However, the prospective students listened to the advice of their parents (41\%), who had higher education degrees ( $48 \%$ of the respondents) and were willing to share their experience and act as role models. This suggests that the HEIs need to use parents as a target group for their marketing activities, as well as work more actively with their alumni, who might become the next generation of parents able to positively influence the HEI's image and help build trust in higher education.

Of the respondents, $48 \%$ studied market trends before entering HEI. However, only $35 \%$ believed higher education provided them with a well-paid job, while $33 \%$ believed the opposite. However, interestingly, $46 \%$ of the respondents wished to make a difference in society in their future occupation. This means that, in their marketing communication, the HEIs should emphasize elements offered by higher education that are intended to make such a difference, e.g. corporate social responsibility, sustainability, and similar elements.

Notably, $31 \%$ of Latvian speaking respondents were unaware of whether their parents were willing to pay for their studies. This might relate to the high percentage (53\%) intending to study through state funded places. Even so, the level of tuition fees was important for most prospective students (51\%), with $45 \%$ having analyzed information on scholarship opportunities and the concession policies of various institutions before making their final choice. Of the respondents, $29 \%$ were considering loans for study opportunities. It can be concluded that prospective students are looking for ways to minimize their monetary investment in higher education and thus HEIs should consider partnering with employers and other organizations to secure financial support that would attract the most talented students through scholarships, grants, financial awards for special achievements, and similar. Additionally more flexible payment terms and conditions should be considered by educational providers.

It is important to note that $54 \%$ of Russian and $28 \%$ of Latvian speaking respondents, after completing secondary school, were willing to attend various short trainings and courses related to their chosen 
occupation. Therefore, HEIs should be more active in offering informal education to youth, and through such, simultaneously obtain additional income and increased awareness of the school brand.

Of the respondents, $50 \%$ demonstrated persistence in entering into higher education, supported by the statement that if they were not accepted for the chosen program at the preferred school they would choose a similar program elsewhere. This means that prospective students primarily choose the program of their interest first and the choice of the institution second. Therefore, it is important for HEIs to study the interests and preferences of prospective students, so they can meet the demands of this younger generation, especially in light of respondents appearing to make such choices primarily by themselves $(71 \%)$.

The research showed that $21 \%$ of the school leavers were planning to obtain higher education abroad, while $45 \%$ were interested in international opportunities, including internships at Latvian HEIs. This means that HEIs should develop international activities such as double and joint degrees, international student exchange, and internships abroad, and communicate to the market more actively about these opportunities.

Internet resources were stated as the main source of information regarding HEIs and their offerings. Of the respondents, 59\% had been searching for information from the HEIs' websites and 49\% were also seeking references. This means that the HEIs need to assign significant attention to their websites, to ensure they are modern in design, interactive, and provide current information. Moreover, it is important for HEIs to have a positive image through use of public relation activities and media resources, in both real and virtual environments.

Of the respondents, $46 \%$ stated that their choice was not affected by advertisements in mass media. This does not mean that schools should not use media channels, but rather they need to be aware of mass media's supportive role in increasing school awareness more so than as a stimulus for prospective students to make specific choices.

A reasonable proportion of the respondents (38\%) had attended educational fairs. Thus, the HEIs should continue to participate and allocate resources in such.

Only $31 \%$ of the respondents found it important to familiarize themselves with the learning environment of the schools, with only $39 \%$ attending open days organized at the HEIs. However, the latter percentage is not that small as to suggest HEIs should discontinue this activity. Nonetheless, it is advisable for HEIs to reconsider the format of open days, to make them more interesting and attractive for youth. Of the respondents, $45 \%$ reflected on the extracurricular activities offered by the school. They regarded an offering of sport and leisure activities and any additional training opportunities by the school as important.

In respect to the importance of location in terms of the choice of HEI, opinions differed with $35 \%$ believing it was not important, $34 \%$ regarding it important, and $31 \%$ having no opinion. It is assumed that students are prepared to travel to whichever HEI meets their expectations regarding the content and conditions of their studies. Nevertheless, the vicinity of public transport and availability of parking areas might affect a student's choice of an institution.

In terms of which factors might better predict the decision of prospective students in choosing a HEI, the correlations among variables are displayed in Table 2. The results show the prospective students' plans to enter HEI significantly correlated $(\mathrm{p}<0.01)$ with cultural, social, psychological, and organizational factors and subsequently all factors were included in the regression analysis.

Psychological factors had the highest correlation with plans to enter HEI $(r=0.58 ; p<0.01)$. In order to understand which variables best predict the decision to enter HEI, a regressions analysis applying stepwise method was used. This method is generally used to define variables that can predict the dependent variable, while removing other variables. It is appropriate for situations with no clear theoretical indication of the independent variables expected to predict the dependent variable (Tabachnick \& Fidell, 2001). The regression analysis included cultural, social, psychological, and organizational factors as independent variables and plans to enter HEI by a prospective student as the dependent variable. Results are shown in Table 3. 
Table 2: Correlation of the indicator of prospective students plans to enter HEI and cultural, social, psychological and organizational factors (Spearman correlation), $\mathrm{N}=644$

\begin{tabular}{llcccc}
\hline Variables & $\mathbf{1 .}$ & $\mathbf{2 .}$ & $\mathbf{3 .}$ & $\mathbf{4 .}$ & $\mathbf{5 .}$ \\
\hline 1. Plans to enter HEI & 1.00 & & & & \\
2. Cultural factors & $0.50^{* *}$ & 1.00 & & & \\
3. Social factors & $0.48^{* *}$ & $0.87^{* *}$ & 1.00 & & \\
4. Psychological factors & $0.58^{* *}$ & $0.87^{* *}$ & $0.87^{* *}$ & 1.00 & \\
5. Organizational factors & $0.46^{* *}$ & $0.69^{* *}$ & $0.80^{* *}$ & $0.76^{* *}$ & 1.00 \\
\hline ** $\mathrm{p}<0.01$ & & & & & \\
\hline Source: Authors & & & & & \\
\hline
\end{tabular}

Table 3: Results of the regression analysis of the plans to enter HEI by prospective students with cultural factors, social factors, psychological factors, and organizational factors as independent variables, $\mathrm{N}=644$

\begin{tabular}{|lcccc|}
\hline Dependent variable: plans to enter HEI & B & SE B & B & $\mathbf{R}^{2}$ \\
Psychological factors & & & & 0.48 \\
& 0.05 & 0.01 & 0.52 & \\
Organizational factors & 0.03 & 0.01 & 0.20 & \\
\hline Note: $\mathrm{F}(1,641)=293.46 ; \mathrm{p}<0.001$ & & & & \\
\hline Source: Authors & & & & \\
\hline
\end{tabular}

Data analyses revealed two variables were statistically significant in predicting plans of prospective students to enter HEI (Table 3). Cultural and social factors were not included; factors included explained $48 \%$ variance of the prospective students plan to enter HEI. The most significant independent variable, explaining $47 \%$ of the variance of the dependent variable, was the grouping of psychological factors. The grouping of organizational factors in this model explained a relatively small part of the variance $(1 \%)$.

Therefore, the highest ability to predict the plans of the prospective students to enter HEI belonged to psychological factors, with some significance in terms of the organizational ones.

\section{Conclusion}

In predicting the plans of prospective students to enter HEI (the dependent variable), the regression analysis indicated psychological factors as the most significant independent variable. This group included an individual's attitude to higher education, its importance and value, role in future life, and career development.

Even though the organizational factors did not display a high proportion of the variance of the dependent variable, this group significantly correlated to the plans of prospective students to enter HEI, and thus shows that prospective students consider various organization attributes of the HEIs such as geographic location, scholarship opportunities, student life, and others that are similar.

This study's findings, to a great extent, correspond to opinions of other authors described in the literature review and provide information on factors that are of great importance to young people of Latvia in choosing a higher education provider. A HEI can use the results in designing various student attraction strategies, and thus increasing their market share and competitiveness. 
This research was limited to local students aspiring to obtain a bachelor degree after completion of secondary schooling. It did not look at factors attracting foreign students to Latvian HEIs; neither did it study prospective candidates for postgraduate studies. These would require additional approaches and will be studied in further research.

\section{References}

Academic information centre (2015). "Accredited programs and fields of study", [01.10.2015], http://www.aic.lv/portal/aikna/akreditetie-studiju-virzieni-un-programmas

Al-Yousef, H. (2009). "They know nothing about university-neither of them went: The effect of parents' level of education on their involvement in their daughters' higher education choices", A Journal of Comparative and International Education, 39(6), 783-798

Ancheh, K. S. B., Krishnan, A. \& Nurtjahja, O. (2007). "Evaluative criteria for selection of private universities and colleges in Malaysia", Journal of International Management Studies, 2(1), 1-11.

Afful-Broni, A. \& Noi-Okwei, C. (2010). "Factors influencing the choice of tertiary education in a Subsaharan African University", Academic Leadership: The Online Journal, 8(2), 1-8.

Beneke, J. \& Human, G. (2010). "Student recruitment marketing in South Africa-An exploratory study into the adoption of a relationship orientation", African Journal of Business Management, 4(4), 435-447.

Bragg, S. (2007). "Student voice and governmentality: the production of enterprising subject", Discourse: Studies in the Cultural Politics of Education, 28(3), 343-355.

Briggs, S. (2006). "An exploratory study of the factors influencing undergraduate student choice: the case of higher education in Scotland", Studies in Higher Education, 31(6), 705-722.

Briggs, S. \& Wilson, A. (2007). "Which university? A study of the influence of cost and information factors on Scottish undergraduate choice", Journal of Higher Education Policy and Management, 29(1), 57-72.

Ceja, M. (2004). "Chicana College Aspirations and the Role of Parents: Developing Educational Resiliency", Journal of Hispanic Higher Education, 3(4), 338-362.

Ceja, M. (2006). "Understanding the role of parents and siblings as Information sources in the college choice process of Chicana students", Journal of College Student Development, 47(1), 87-104.

Central statistical bureau (2013). "Population - key indicators", [08.07.2013], http://www.csb.gov.lv/statistikastemas/iedzivotaji-galvenie-raditaji-30260.html

Central statistical bureau (2015). "Educational institutions and number of students", [01.10.2015], http://data.csb.gov.lv/pxweb/lv/Sociala/Sociala_ikgad_izgl/IZ0010.px/table/tableViewLayout1/?rxid=cdcb978c-22b0416a-aacc-aa650d3e2ce0

Cubillo, J. M., Sánchez, J. \& Cerviño, J. (2006). “International students' decision-making process”, The International Journal of Educational Management, 20(2), 101-115.

Datar, S. M., Garvin, D. A. \& Cullen, P. G. (2010). Rethinking the MBA: Business Education at a Crossroads, Harvard University Press, Boston, MA.

Dawes, P. L. \& Brown, J. (2002). "Determinants of awareness, consideration, and choice set size in university choice", Journal of Marketing For Higher Education, 12(1), 49-75.

Dawes, P. L. \& Brown, J. (2005). "The Composition of Consideration and Choice Sets in Undergraduate University Choice: An Exploratory Study”, Journal of Marketing For Higher Education, 14(2), 37-59.

Domino, S., Libraire, T., Lutwiller, D., Superczynski, S. \& Tian, R. (2006). "Higher education marketing concerns: factors influence students' choice of colleges”, The Business Review, 6(2), 101-111.

Ellis, N. \& Moon, S. (1998). "Business and HE links: The search for meaningful relationships in the placement marketplace part two", Education \& Training, 40(9), 390-397.

Gati, I. \& Asher, I. (2001). "The PIC model for career decision making: Prescreening, in-depth exploration, and choice", in T. L. Leong \& A. Barak (Ed.), Contemporary models in vocational psycholog y: A volume in honor of Samuel H. Osipow, New Jersey: Lawrence Erlbaum, 6-54.

Gati, I. \& Tal, S. (2008). "Decision-making models and career guidance”, in J. A. Athanasou \& R. Van Esbroeck (Ed.), International Handbook of Career Guidance, Sydney: Springer, 157-185.

Germeijs, V., Luyckx, K., Notelaers, Gl, Goossens, L., \& Verschueren, K. (2012). "Choosing a Major in Higher Education: Profiles of Students’ Decision-Making Process”, Contemporary Educational Psychology, 27(3), 229-239.

Goff, B., Patino, V. \& Jackson, G. (2004). "Preferred information sources of high school students for community colleges and universities", Community College Journal of Research and Practice, 28(10), 795-803.

Govan, G. V., Patrick, S. \& Yen, C. J. (2006). "How high school students construct decision making strategies for choosing colleges", College and University, 81(3), 19-29.

Ho, H. F. \& Hung, C. C. (2008). "Marketing mix formulation for higher education”, The International Journal of Educational Management, 22(4), 328-340.

Hossler, D. \& Gallagher, K. (1987). "Studying student college choice: a three-phase model and the implications for the policymakers", College and University, 2(3), 207-221. 
Hossler, D., Schmidt, J. \& Vesper, N. (1999). Going to College: How Social, Economic and Educational Factors Influence the Decisions Students Make, Baltimore, MD: The Johns Hopkins University Press.

Hoyt, J. E. \& Brown, A. B. (2003). "Identifying college choice factors to successfully market your institution", College and University, 78(4), 3-10.

Ivy, J. (2001). "HEI image: a correspondence analysis approach”, International Journal of Educational Management, 15(6), 276-282.

Ivy, J. (2008). “A new higher education marketing mix: the 7Ps for MBA marketing”, The International Journal of Educational Management, 22(4), 288-299.

Judson, K. M., James, J. D. \& Aurand, T. W. (2004). "Marketing the university to student athletes: Understanding university selection criteria", Journal of Marketing For Higher Education, 14(1), 23-40.

Kim, D. (2004). "The effect of financial aid on students' college choice: Differences by racial groups”, Research in Higher Education, 45(1), 43-70.

Kittle, B. \& Ciba, D. (2001). "Using College Web Sites for Student Recruitment: A Relationship Marketing Study”, Journal of Marketing For Higher Education, 11(3), 17-37.

Kotler, P., \& Fox, K. (1995). Strategic Marketing for Educational Institutions, (2nd ed.), New Jersey: Prentice Hall.

Kusumawati, A., Yanamandram, V. K. \& Perera, N. (2010). "University marketing and consumer behavior concerns: the shifting preference of university selection criteria in Indonesia", 2010 Asian Studies Association of Australia 18th Biennial Conference, 1-16.

Litten, L. (1980). "Marketing higher education: Benefits and risks for the american academic system”, Journal of higher education, 51(1), 40-59.

Ministry of Education and Science (2015). "Overview of the Latvian higher education in 2014. Key statistics", 93p.

Moogan, Y. J. \& Baron, S. (2003). "An analysis of student characteristics within the student decision making process", Journal of Further and Higher Education, 27(3), 271-287.

Nicholls, J., Harris, J., Morgan, E., Clarke, K. \& Sims, D. (1995). "Marketing higher education: The MBA experience", The International Journal of Educational Management, 9(2), 31-38.

Nora, A. (2004). "The Role of habitus and cultural capital in choosing a college, transitioning from high school to higher education, and persisting in college among minority and nonminority students", Journal of Hispanic Higher Education, 3(2), 180-208.

Paulsen, M. B. (1990). “College Choice: Understanding Student Enrollment Behavior”, ASHE-ERIC Higher Education Report, 6, Washington, DC: The George Washington University, School of Education and Human Development.

Pimpa, N. \& Suwannapirom, S. (2008). "Thai students' choices of vocational education: marketing factors and reference groups", Educational Research for Policy and Practice, 7(2), 99-107.

Quigley, C. J., Bingham, F. G., Notarantonio, E. M. \& Murray, K. (2000). 'The Impact Discounts and the Price-Quality Effect Have on the Choice of an Institution of Higher Education”, Journal of Marketing For Higher Education, 9(2), 1-17.

Raposo, M. \& Alves, H. (2007). “A model of university choice: An exploratory approach”, Proceedings of the 29th Annual EAIR Forum: In search of Identity: Dilemmas in Higher Education”, 26-29 August 2007, Innsbruck, Austria.

Tabachnick, B. G., \& Fidell, L. S. (2001). Using multivariate statistics, Boston: Allyn and Bacon.

Tapp, A., Hicks, K. \& Stone, M. (2004). "Direct and database marketing and customer relationship management in recruiting students for higher education”, International Journal of Nonprofit and Voluntary Sector Marketing, 9(4), 335-345.

Tavares, D., Tavares, O., Justino, E. \& Amaral, A. (2008). "Students' preferences and needs in Portuguese higher education", European Journal of Education, 43(1), 107-122.

Veloutsou, C., Lewis, J. W. \& Paton, R. A. (2004). “University selection: information requirements and importance”, The International Journal of Educational Management, 18(2/3), 160-171.

Wagner, K. \& Fard, P. Y. (2009). "Factors Influencing Malaysian Students' Intention to Study at a HEI", Chinese American Scholars Association, New York, New York, USA, Retrieved 30 September, 2015, from http://www.gcasa.com/PDF/malaysia/Wagner-Fard.pdf

Wiese, M., van Heerden, N., Jordaan, Y. \& North, E. (2009), “A marketing perspective on choice factors considered by South African first-year students in selecting a HEI”, Southern African Business Review, 13(1), 39-60.

Yamamoto, G. T. (2006), “University evaluation-selection: a Turkish case”, The International Journal of Educational Management, 20(7), 559-569.

Yokoyama, K. (2008), "Neo-liberal governmentality in the English and Japanese higher education", International Studies in Sociology of Education, 18(3), 231-247.

Yost, M.; Tucker, S. (1995), "Tangible evidence in marketing a service: The value of a campus visit in choosing a college", Journal of Marketing for Higher Education, 6(1), 47-67. 